DOI https://doi.org/10.36059/978-966-397-111-7/133-151

\title{
MORALITY AS A SPECIFIC FORM OF HUMAN ACTIVITY MOTIVATION
}

\section{Tymoshenko T. S.}

Methodological content of activity approach to the problem of moral choice is in the spreading general principles of human activity analysis in general as well as purposeful approach on ethic studies - the analysis of correlation of goals, means, and results in particular. Special distinction of such universal activity features in morality allows making a decision on whether the choice of purposeful means is an integral element of the system, namely, moral activity, whether the criterion of purposefulness is external and such that does not express the essence of moral choice, and the latter is exhausted by axiological advantage, contains the value without regard to the effective realization of the set goal.

Determination of morality and human activity correlation as an aspect and the whole determines the destiny of ethical-praxeological study of moral choice, including its framework in general-philosophical target analysis. The target analysis defines such general features as axiological and praxeological ones in the moral activity, and determines the role of morality in regulating these aspects of moral activity. As a result, the object of ethical-praxeological research of moral activity in general and moral choice, in particular, manifests itself in both moral evaluation of human praxeological activity and praxeological evaluation of the moral aspect of human activity, and the very practical aspect of choice serves as an element of the whole, namely, moral activity.

Moral activity as an aspect of human activity means the application of such aspect of the target analysis to the study of morality as praxeological one. In relation to this, it seems necessary to express our attitude to the position of those authors who represent moral activity only in axiological terms, and thus try to identify the essence of distinction, since, finally, it appears that these distinctions express and define the idea about the structure of moral activity in general and moral choice in particular. 
The first distinction between the points of views consists in determining the moral activity either as a type - an independent phenomenon of human activity, having its own "sector" in the field of human activity, or as parties, an aspect of human activity, an angle of its entire field. It should be emphasized that in modern works on ethics the attitude to morality as an autonomous domain of public life is practically overcome. It often occurs in the form of eclectic insertion into a different point of view, and it is precisely this shift that makes it difficult to clarify its essence and the problem of its criticism.

One of the most common is the distinction between moral activity as behavior focused on moral values, and the moral aspect of human activity, that is, the possibility of moral evaluation application to the actions of people $^{1}$. The reason for such division is the opposition of intentional and moral actions as well as such actions that did not become a consequence of moral motivation.

This opposition is rather attractive, but it gives rise to doubts whether it is possible to accurately call "morally unmotivated" actions as a "moral aspect of human activity". Both types of actions are the objects of moral regulation, and therefore both should be called "moral aspect of human activity" or simply "moral activity". Therefore, it does not seem convincing to distinguish between moral significant actions, that is, those that fall under the moral evaluation, but not governed by the moral consciousness of a person and actually moral actions ${ }^{2}$ if in relation to one another no generic-specific bond is established, since both options of actions are subject to moral evaluation and differ only in degree (level) of motivation.

In relation to awareness and unawareness of the human activity motives, it should be noted that "unmotivated" activity is practically not "without motives", but only motivated in a hidden form. ${ }^{3}$

The second distinction lies in the very characteristic of morality as an aspect of human activity, in meanings enclosed in the features of morality, expressing its universality and specificity. A peculiar manifestation of this

${ }^{1}$ Скрипник А.П. Моральное зло в истории этики и культуры. М.: Политиздат, 1992. - 211 с. Ст. 30-31.

2 Николаичев Б. Осознаваемое и неосознаваемое в нравственном поведении личности. М.: Изд.-во МГУ, 1976. - 96 с. Ст. 17.

${ }^{3}$ Леонтьев А. Деятельность. Сознание. Личность. - М., Наука, 1989. - 566 с. - Ст. 102. 
discussion about the meaning of "moral aspect of human activity" concept is the isolation of "actual moral activity", which is proceeded the characteristics of human activity specifics in an effort to go beyond the attitude to it as "only an aspect" that should be considered in more detail.

In case when public activity does not have its proper moral purpose, but in the hierarchy of its motives there is a moral motive, we can speak about the moral aspect of activity, emphasizing that such a division of the actual moral activity and the moral aspect of an activity includes, as a methodological basis, the concept of O. Uledov about the specificity of morals.

O. Uledov speaks about illegality of ignoring the specificity of morality, emphasizing that morality is a side, an aspect of human activity. He notices that the universality of moral relations does not mean that they represent only an aspect of public relations from the point of view of ethical categories. The essence of the issue is in the fact that moral relations have their specificity ${ }^{4}$. However, justice requires a true evaluation of both features: both universality and specificity, moreover, not on the principle of "both are important", but taking into account the specific place of each feature.

Being independent and specific, morality is an aspect of human activity, not in the same sense that it is interpreted from the point of view of categories of ethics, but in the above-mentioned sense, as parties, an angle of human activity.

Moral activity is an aspect of human activity, and therefore the very concept of "moral activity" is rather conditional and should not be interpreted as a particular personified form of human activity. Every kind of human activity has a moral side. Specifying this approach, O. Drobnitsky wrote that a moral activity is a moment in any activity where it is subject to moral regulation, determined by moral relations (falls under the relevant provisions and prohibitions, is motivated by moral tasks, included in the field of moral guidance, becomes an object of moral evaluation). This activity serves as realization of duty (while being determined by a range of other social factors). ${ }^{5}$

\footnotetext{
${ }^{4}$ Уледов А. Структура общественного сознания. - М.: Мысль, 1988. - 324 с. - Ст. 63.

5 Дробницкий О.Г. Проблемы нравственности. - М.: Наука, 1977. - 333 с. - Ст. 192-193.
} 
It is understood that it does not appear from this that the concept of "actual moral activity" should be put aside. Moreover, we consider it is reasonable to use it, but in case when it means the characteristic of selfgoal of moral activity. So, O. Tytarenko believes that there should be the same self-goal of moral activity in society as another person's interests, the need to communicate with people, unselfishness of making the good, focusing on the rise of spiritual life, etc. ${ }^{6}$. Without going into the special analysis of the issue, we should note that all self-goals in the final conclusion are derivative or subordinated to moral self-goals. Thus, the distinction of "actual moral activity" is relevant and reasonable, but the content implicit in this expression should be limited to the following: "a self-goal of moral activity as an aspect of human activity.

The above mentioned points of view on moral activity show that in the issue of whether moral activity is an independent phenomenon of human activity or its aspect in a hidden form contains a more fundamental issue about the universal character of human activity features and their applicability in the study of morality.

At the same time, inconsistency in relation to moral activity as to the moment, the aspect of human activity, deprives the researcher of the opportunity to use the methodological approach of an activity approach in full. This concerns, firstly, the point of view of moral activity as merely spiritual, having no material embodiment within the framework of morality, and secondly, the point of view of the "operational" - praxeological element in the act as a foreign in specificity of moral activity.

The urgent necessity for self-determination of morality, repetition of the vulgar understanding of its specificity, the traditional explanation of morality only as a form of public consciousness gave rise to one-sidedness of the inverse property, being reduced, in turn, into the spiritual activity only. At the same time - and this is naturally - two points of view appear to be interconnected. We would like to refer to two ethical works that reflects this problem.

$\mathrm{V}$. Sherdakov believes that it is necessary to distinguish between acts in the choice of which there are moral motives, from those which a person performs without moral motivation. The latter, from his point of view, fall

\footnotetext{
${ }^{6}$ Титаренко А.И. Структуры нравственного сознания. - М.:Мысль 1974. - 278 с. - Ст. 275-276.
} 
within the moral evaluation because they express conscious acts of will, that is, a person's choice is manifested. However, agreeing to name the acts in the choice of which the moral motives appeared, "embodied in the moral consciousness", the author notes that the "moral action" concept means only the motivation of an action or its accountability to moral evaluations, and acts (actions) do not relate to morality, since "there is no substance of morality here"7. As we can see, this conception by distinction of moral-motivated and non-motivated actions shows a relevant point of view on moral activity, the peculiarity of which is the breakup of the activity elements.

The rejection of "substance of morality" existence appears here not in the sense that - as we would say - this "substance" is all human activity, any kind of it, but in the fact that the moral activity excluded means and results that make up "material" element of the act as a whole and a moral choice as its moment.

G. Humnitsky distinguishes ethical behavior from the entire set of human activity as a moment having a specific integral characteristic. At the same time, the author considers it necessary to distinguish between behavior and activity, since, firstly, from his point of view, moral activity is understood only as "the process of moral choice that occurs in subject's psyche, but not behavior itself', and secondly, any technology inherent in all types of human activities, any kind of operation is not connected with a moral behavior ${ }^{8}$. Dividing the moral behavior evaluation as a moment of human activity, we should recognize the similarity of positions of the above authors, who identified moral activity and reduced it to spiritual activity.

The pointlessness to consider moral activity only from the spiritual point of view becomes obvious as a result of understanding the distinction falseness between forms of public consciousness to counterbalance their real content. The methodological reason for this false distinction is, according to V. Rotnitsky, firstly, in the metaphysical interpretation of relation between form and content, according to which the form in its opposition to the content does not depend on the content, and can also be

\footnotetext{
${ }^{7}$ Шердаков В. Аксиология и этика. Тбилиси: Изд. - во Тбилиского университета, 1990. - 168 с. Ст. 156-158.

${ }^{8}$ Гумницкий Г. Основные проблемы теории морали. - Иваново, 1992. - 227 с.- Ст. 22.
} 
a "repository" of any content, and secondly - in the identification of the content of public consciousness forms with existence in general, that is, in the identification of public existence as an object of reflection with the object of reflection. ${ }^{9}$

Each form of public consciousness has its own subject.

However, the object of any form of social consciousness is not an entirely separate part, separated by the sector of public existence; it is a part of a complicated structure of public existence as a whole. This approach is the basis for understanding the unity of all forms of public consciousness and their specifics, implemented in public practice. Therefore, the forms of public consciousness relate to everything in public existence, but to its different sides. In this sense, each form of public consciousness is universal and specific in various ways.

As for morality, this means that, firstly, it is universal - any act of human activity has a moral value. Reflecting moral existence, moral consciousness, in turn, is objectified in it and, therefore, secondly, the universality of morality can be represented as the universality of moral activity in the unity of its material and spiritual sides.

An important step in overcoming the absolutization of morality spiritual side is in the correct issue resolution on correlation of existence and consciousness in it, in the distinction of "morals existence". In a number of recent works it is rightly emphasized that the materialist conception of morality requires the consistent application of the philosophy basic issue and in the field of moral activity. V. Vasilenko believes that the desire of many researchers to "catch" the subject of ethics in full, to complement the results of moral consciousness study yet obtained, to complement a subjective-spiritual component of morality by content analysis of real moral actions, situations and relationship is absolutely justified both in the historical-philosophical and in the immanent-logical terms. ${ }^{10}$

Even a special research goal - an analysis of the "morals language", such specific mechanisms of moral consciousness as motivation, sense of responsibility, conscience, etc. does not give the right to forget about

\footnotetext{
${ }^{9}$ Ротницкий В. Диалектика форм общественного сознания. - Тюмень: Изд.-во Тюменьского университета, 1993. - 356 с. - Ст. 166, 171.

10 Василенко В. Сознание и бытие в структуре нравственного феномена. - М.: Наука, 1991. 166 c. - Ст. 57.
} 
moral activity as a system of elements in which means of self-regulation of morality are, finally, the means of regulation of all human activity.

At the same time it is not right to imagine the moral activity as such that is close to the moral consciousness.

So, the interpretation of moral activity as a separate type of human activity can not be right because it leads to opposition of material and spiritual elements of morality to absolutization of moral consciousness features and their reduction to the moral activity essence in general. The definition of moral activity as an aspect of human activity makes it possible to apply a "targeted analysis" to morality itself and thus to reveal the impermissibility of ideas about it as a solely spiritual phenomenon.

The degree of application sequence of moral activity concept as an aspect of human activity and, thus, a targeted analysis of moral choice determines the ideas of researchers about the structure of an act as a "cell" of moral activity and, first of all, about the role of "operational" element of the act, its relation to moral choice and morality in general. The principal significance in this regard has the traditional distinction between "actions-operations" and "actions-acts".

It should be noted that the necessary foundation for the moral evaluation of the act in general, including moral choice, is the unity of motives and results. However, frequent mismatches and non-conformity between the motive and the result caused by objective circumstances, not depending on a person make the ethics scholars adjust the requirements for an act. Striving to avoid the extremes, namely, absolutization of a role of the motive or the result, some authors make a suggestion to formulate the basis for evaluating the moral act in another way and thus eliminate the interference of external circumstances from the factors that analyze moral activity. Since this interference is expressed, first of all, in the result of an act, a sufficient basis is the unity of motive and act as a practically meaningful act.

However, the exclusion of such activity element as its results from the moral evaluation basis does not allow considering the unity of motive and action to be a sufficient ground, if we understand under the action according to O. Leontiev's definition - the purposefulness of a practical phase of the act. The correlation of motive and action lead necessarily to the fact that the act is qualified as morally positive or immoral only if the 
action is seen as the unity of goals, means and results. Although, in this case, it is necessary to adjust the traditional grounds for evaluation of an act as well, namely, the correspondence of motive and result.

Methodological comprehension of analysis significance in a moral choice of a goal, means and result in terms of the necessity and adequacy of these elements, the recognition of their unity for the moral choice of human activity principles is an urgent task of ethical theory in general and of the theory of moral choice as well.

The situation of moral choice appears in case when a subject has the necessity to make a decision on appropriate option of the act. However, the condition for the emergence of moral choice necessity is the objective opportunity to act in one way or another, to choose moral goals and means of their implementation. A range of such opportunities is an objective determinant of situation of moral choice. Together with the dependence of the act choice on the subject itself, on its ability to give preference to positive moral values and to determine the optimal ways to achieve it, we thus distinguish two elements of any moral choice situation: the opportunity to choose and the ability to choose. Thus, the diversity of situation in our case is limited to the actual praxeological aspect of the limits and requirements of moral choice; the subject and the object of situation act at an appropriate angle, which, of course, takes into account the type of situation and the challenges of its solution.

In modern scientific literature there is not any special research on the types of moral choice situations. The lack of classification sometimes gives rise to inadequate application of other science provisions about human activity to the actual moral choice situation. At the same time, in order to overcome the difficulties of ethical research, the correct use of achievements in these sciences is necessary.

In these terms the works of K. Novikov are of great interest. Studying the philosophical aspect of the freedom of choice, the author distinguishes the following types of choice: 1 ) by their significance; 2 ) by the degree of their generalization; 3) by the degree of heuristicity. The author deduces his classification of choice types from the analysis of a social domain of acts of subject's choice. To what extent such human activity, its connection with nature, society and other people is diverse, the author points out, and to the same extent their choice is diverse. The diversity of 
the social domain where personalities express themselves determines the specific variety of choice. ${ }^{11}$

In the content of significance concept the author includes the objective and subjective value of act, its public and personal sounding. In this regard, in the first type, he divides the acts of subject's choice into the following classes: public and personally significant, public significant, personally significant.

Characterizing the second type of choice, K. Novikov distinguishes between levels of generalization and socialization of choice. The author points out that the freedom of choice is considered at the appropriate level of generalization, depending on the object of choice, such "volume" that it occupies in the social space (the choice concerning the destiny of mankind, within a small social group, an individual choice). And the level of socialization shows how much this or that particular act (whether it relates to the destiny of mankind, social system or a separate social group) has become a group, mass, and universal one. ${ }^{12}$

The author distinguishes the third type of choice by the degree of their creative principle, separating it from situations in which reproductive thinking is used.

As a working concept, such classification of acts of free choice can be applied to ethical research as well. However, without criticizing K. Novikov's concept, we should note that a holistic approach, that is, the classification of situation in the unity of its subjective and objective moments, is more effective for the praxeological approach to person's moral choice. In this case, we can make a conclusion not only that the high scale of the object's moral choice determines a less high (the choice of meaning of life - single acts), and the subject's choice of such scale as a class, a group - the individual's choice, but also about that the individual situation of moral choice embodies the essential features of the election situations of a group, a class, and society as a whole.

The subject of the moral choice situation can be quite diverse: it is the individual who chooses the appropriate act; and a group of people who define the norms of mutual relations between each other; a class that

${ }^{11}$ Новиков Б.В. Контуры духовности. Новые контексты идентификации // Вопросы философии. 1992. - № 12. - С. 21-41. - Ст. 39.

${ }^{12}$ Там само. - Ст. 38. 
strives to change or maintain its socio-political structure; finally, society as a whole, which decides on the prospects of its development.

Yet such an approximate understanding of the situation subject contains information on diversity of the moral choice object. These include such moral phenomena as the choice of a single act and ideals; the meaning of life and the line of behavior; goal-purpose and means of its implementation, etc. The fact that we encounter in the study of a moralpraxeological aspect of the moral choice situation is that the moral activity variation concept, the necessity for a plurality of options for moral solutions and the means of their implementation, that is, in our aspect - an objective opportunity to choose, does not mean social and moral limitlessness of the moral choice range. An opportunity to choose determines the way of human life, its place in the system of public relations, defined and secured in the culture by the systems of moral values.

The social dependence of the moral choice involves, first of all, the nature of objective opportunities to act in one way or another, since a person can always choose between the relevant things being a part of their life cycle. The formal diversity of behavioral options are strictly limited by social circumstances, the range of decisions is significantly different in people with unequal status in the structure of society. Social dependence of the choice opportunities is connected with worldview and moral dependence of human decisions, with the internal determination of acts. A certain decision about the most acceptable option of an act is no less important condition of choice than an objective opportunity to act in one way or another; however, all the above is not resulted in the fact that moral choices can be made beyond the limits of good and evil. The consideration of the moral acceptability of alternatives not less determines the decision of a person than the consciousness of objectively impossible options for action under the relevant social circumstances.

Moral behavior of an individual, a social group, a class also provides for a moral necessity, namely, the expression of human act determination by systems of moral norms and values existing in society. Moral necessity is reflected in consciousness in the form of a goal (aim), which individuals must implement in their behavior. Therefore, a moral choice can be truly free only if it is the result of the conscious, and the one that meets this necessity for a solution. By consciously making a decision, a person 
transforms the moral necessity from external reason acting beyond the person's will into self-determination. In this sense, the relation of freedom and the necessity of choice acts as a dialectical relation of cause and effect in the chain of human acts: being a precondition for moral choice in the historical-genetic relation within the framework of certain actions human activity itself serves as a product of moral regulation. In other words, freedom of choice is a condition of person's morality, but since the choice is limited to the range of good and evil, then a person regulates the freedom of choice independently. It is this approach that allows explaining the fact that in specific selective situations, moral freedom can not be a condition, but a consequence of the mechanism of moral regulation.

Therefore, the awareness of personality's moral choice as an act of moral activity, arising in a situation that requires the benefit of one of the act options, and is expressed in the moral purpose production of the decision on effective means of achieving the goal and implementation of the moral solution, the practical implementation of it according to the moral goals of the result, is based on the active approach to morals. This approach allows distinguishing the universal features of human activity in morality, and thus applying a "targeted approach" to the moral choice: an analysis of the relation of goals, means and results. The significance of a moral-praxeological study is determined by the fact that the effectiveness of moral choice determines the implementation of its value orientation.

The issue of specificity of morality has often appeared in the form of an issue about the nature of moralistic activity itself, its relationship with the everyday life of a person. From ancient times to the present, two opposing models of understanding of this problem have been traced in ethics. In the hedonistic model, morality was deduced from the "ordinary" human nature, from their vital demands, it means that people themselves are interested in implementing moralistic demands. This tradition has reached its highest development in the concept of "reasonable egoism", but in history, morality demands as an internal factor of human activity often entered into a sharp contradiction with the aspirations of the individual. In moral consciousness it was formed in the form of a thought about the eternal conflict between aptitude and obligation, practical calculation and high motive, being the basis for a rigorist model, within which there are ethical concepts of Stoicism, Kantianism, most of the trends of Christianity 
and Eastern religions. Representatives of such approach consider as impossible to deduce the justification of morality from the human nature and they interpret morality as something initially opposite to the practical interests and natural aptitude of people. From this opposition, firstly, the ascetic understanding of moral activity as a severe oppression of own natural aspirations by a person is originated, and the spontaneous aspiration to good is considered as moral one only conditionally and not in full (Luther, Kant, Barthes). Secondly, this is also connected with a pessimistic evaluation of the human moralistic capacity, the thesis of Protestant neo orthodoxy about the impossibility of practicing real morality in mortal life, provisions of existentialism about the fundamental human incapability to implement their ideals. Such understanding of moralistic activity, as well as the idea of not revealing the moral principles from human existence and about the impossibility of finding the basis of morality in the domain of existence, was embodied in the concepts of autonomous ethics, which in the 20th century took a position on denying the socially reasonable nature of moralistic activity, which is typical of existentialism, neo orthodoxy, deontological intuitivism.

An essential impulse to the development of this problem was given during the Renaissance. For example, in the views of M. Montaigne, one can observe a person and their life not through the prism of metaphysical synthesis and abstract harmony, but in the dramatic conflict appearing when the personal and the social come into collision. He cares about the difference between morality and customary-traditional guidance. He formulates this problem in the spirit of his time. Human customs are quite diverse, commonly accepted views are diverse; there is no place for the only truth and verity equal to all. The most ridiculous fiction can be a "commonplace custom" for a certain people, but where this custom is practiced, and all deviations from the custom are considered to be deviations from mind. Customs and goodness, "which are commonly said to be generated by nature, are generated in fact by the same custom" 13 . Such goodness is conditional and conventional, but not intelligent in the true meaning. The generally recognized custom is not at all a guarantee that the actions appropriate to it will always be virtuous, subject to the

\footnotetext{
${ }^{13}$ Монтень М. Опыты в 3-х кн. - М.: Голос, 1992, кн. 1. - 383 с. - Ст. 146-149.
} 
principles of morality. Montaigne points to "injustice of our customs". The common habit "shields the actual state of things". Taking off a disguise from the similar things and comparing it with the truth and mind, a person will feel that, although their previous judgments have changed, yet the basis under feet has become harder anyway. In his opinion, when making judgments it is necessary to rely on own mind but not public opinion. ${ }^{14}$

The customs establishing in a particular people is not yet morality or real goodness. In order to understand the true goodness, one should "take off a disguise" of external public institutions, turn to the own mind.

At the end of the 16th century, in the era of the development of individualism, egoism and political ambition, internecine wars and religious conflicts, the illusion that in the decision of moral issues it is possible to rely on a person, on their natural needs and aspirations, on the internal laws that people can draw from themselves was defeated. Montaigne, clearly noticing this critical problem of time, sees "love for themselves and a high opinion of themselves as excessive, where own views are placed on a high level so that for the benefit of their triumph not to stop due to the violation of public peace ... Ordinary law order does not recognize exceptional cases, because human life provides for an orderly community in which everyone performs the duties assigned to them and everyone mutually observes the unified laws. In any innovations he sees the desire to conquer the established public rules and establishments of tyranny instability" ${ }^{\prime 2}$. Montaigne does not conceal the sources of his own fear for the high thought about him of someone who breaks the laws of the custom as well. These are internecine wars and hostility between political and religious camps, the irresponsibility of lawmakers, ready to arrange everything in a new way, the fanatical selfconfidence of struggling parties, when each of them strives to impose its other truth without wanting to know the arguments of the other party, martially intolerance and contempt for something that is unattainable to us. "It's unreasonable to judge what is true and what is wrong based our awareness", writes Montaigne. He points out to the "wise men" who value everything according to their own measure, dishonoring the goodness of others. $^{16}$

${ }_{15}^{14}$ Монтень М. Опыты в 3-х кн. - М.: Голос, 1992, кн. 1. - 383 с. - Ст. 148, 149, 154, 287.

${ }_{16}^{15}$ Мур Дж. Принципы этики. - М.: Прогресс, 1984. - 326 с. - Ст. 149.

${ }^{16}$ Монтень М. Опыты в 3-х кн. - М.: Голос, 1992, кн. 1. - 383 с. - Ст. 227, 279. 
It appears that the "ridiculous thoughtlessness" of high thought about oneself is based on something that is inherent in the customary-traditional, private-local, closed-state view of things, from the desire to measure everything by its own measure and not to accept something that is far from personal point of view. Therefore, not only the social customs, against which we stand, have become spoiled, but also ourselves become the same: "Evil is in our souls, and the soul is unable to escape from itself." So, true goodness does not exist either in public nature, or in the soul of the individual. Montaigne comes to the conclusion that in our own public activities we must adhere to the established order, "everyone must obey the laws of the state in which they live," but "society has nothing to do with our views." 17

According to the Montaigne, public life with its laws, needs and interests, can not be the basis of real goodness. "The common benefit requires that people go for treason, lie, and merciless destruction in its name." Telling lies "often brought benefits, and most of human matters exist at its expense and rely upon it. There are drawbacks, respected by laws, and there are "good or excusable acts that are illegal in one way or another". So, public usefulness and morality are different things. "We mistakenly consider usefulness as the measure of honesty and beauty of one or another act," but one should make "the difference between useful and honest, consider natural acts as not only useful and essential, but also dirty and dangerous." Montaigne claims that it is also wrong to assume that human communities "exist at the expense of the goodness of their members. They "are formed and survive, no matter what it costs to them."

People "created a political associations from own drawbacks as well as goal-oriented settled and fair society". ${ }^{18}$

So, it appears that morality can not be based on either personal or public interests: it does not coincide with either one or the other. Such conclusion creates a complex problem for moral theorists regarding the basis of goodness, if it is not based on either personal or public needs of a person, but contradicts one and the other. In the future philosophical thought will unsuccessfully try to solve this problem, seeing in it the most significant thing in the specific nature of morality.

\footnotetext{
${ }^{17}$ Монтень М. Опыты в 3-х кн. - М.: Голос, 1992, кн. 1. - 383 с. - Ст. 151.

${ }^{18}$ Монтень М. Опыты в 3-х кн. - М.: Голос, 1992, кн. 1. - 383 с. - Ст. 151.
} 
Summing up philosophical-ethical concepts of the specificity of morality, it can be concluded that morality was reduced in its theoretical explanation: firstly, either to the human nature, reasonable legislation, public life organization or to the cognition of the world and the person. Secondly, its specificity was understood, albeit in different ways, but it was determined by referring to some simple evidences of moral consciousness, that is, it was acknowledged but did not analyzed.

The internal connection of philosophical problems with certain areas of the moral worldview is definite, but there are also fundamental differences between these two ways of thinking. Therefore, the issue about correlation of philosophy with moral consciousness has repeatedly become an urgent problem. Philosophers not only consciously or unconsciously took some moral postulates and moralistic ways of argumentation into their system of judgment, but also sometimes critically perceived the reproduction of moral ideas in the field of philosophical thinking, opposing the strict objectivity of impartial research or real historical experience to naive moralization.

Moral regulation of human behavior in society is carried out due to the internal conviction of the personality, public opinion, tradition, and moral authority. Morality covers a wide range of public phenomena. As a regulatory institution of society, it includes moral consciousness, moral relations, and moral activity. Morality is not only a form of public consciousness, as it has been thought earlier, but also a social institution, performing (together with the regulatory function) functions of cognition, communication, education, inheritance, etc. in society.

The center of moral regulation is a moral norm having a general character. If religion appeals primarily to believers, then morality is equally demanding for all. The generality of moral norm does not consist in the fact that nobody ever violates it, but that every person needs its observance for themselves. Moral norms allow a person to evaluate their own and others' acts, to compare them with the standard, to direct and regulate relations with other people. The moral norm appears at the same time in three main qualities - as norm-prohibition, norm-instruction and norm-order. Simple moral norms - the ideas of people about good, evil, duty, happiness, justice - are passed from generation to generation. Of course, they are predetermined in a certain historical way; they are marked by the 
contradictions of those or other periods of society's life, social cataclysms. However, the overall humanist basis remains unchanged. Simple norms of morality (and due to their simplicity, they are manifestation of the most generalized moral requirements and instructions) have universal nature and such a wide range of regulatory action, that it is even difficult to determine more or less obvious limits of their functioning.

The systematization of mankind moral regulators is a very complicated matter. Experience shows that morality can not be introduced into any list of standards. Any regulation of morality creates a dead end. Exception is probably only the Bible, because it does not have artificial moral systems, but only records things verified by the experience of mankind moral communication: "In everything, act in the way as you want others to act in relation to you." However, this does not mean that ancient moral standards can not be brought into the system, united by a principle, an idea, and an ideal. On the contrary, only in the system they are able to fulfill their regulatory function. Searching for uniting principles, ideas, and ideals has been started in old times and has not finished yet. So, mankind refers to such thinkers as Confucius and I. Kant once again. It was Confucius who found the formula of the eternal moral law for 500 years before our era: "What you do not want to be done for yourself, do not do for others". I. Kant interpreted this formula in the context of the Western civilization categories: "Act in such way so that the maxim of your behavior was the law of conduct for all". 19

Moral regulation is based on the public opinion and conscience of each person. Its power and secret of its application effectiveness to almost all areas of public life and, at the same time, its weakness is in this. If a person has no conscience, moral regulation is powerless. Public opinion can judge (psychologically, morally), although it can not punish. So many people ignore its demands, despise the traditions, they do not recognize the common cultural values. Of course, in this case, morality is powerless, but people are not. In view of this, they continued to look for new regulatory mechanisms of life activity and, finally, they found them.

The law has become one of the most effective mechanisms for regulating of the functioning and development of society at the stage of its

\footnotetext{
${ }^{19}$ Кант И. Основы метафики нравственности. - М.: Мысль, 1999. - 528 с. - Ст. 91.
} 
class polarization. The source of law is, probably, in the public practice of people, which polarized their relations (due to the division of labor and private property), which made it impossible to regulate them by religion and morality. The state generalized natural relations of people contacting in a society divided into opposing classes. The generalization acquired the status of the norm, later on - the law, and performed a regulatory function, based on the authority and power of the state.

Organic unity of legal regulators with state structures creates another qualitatively new mechanism of regulation, functioning and development of society, which is called politics. Politics as a regulatory mechanism covers, first of all, relations between large social groups - classes, nations, nationalities, etc. However, it does not ignore personality. The subject of social development is individuals and social communities. The politics concerns all people together and every personality in particular. Regulatory opportunities of politics are not limited to the area of society economic life. Politics passes through science and culture as well as a social domain. The politics advocates public interest, so there is every reason to speak about economic, cultural, scientific, social policy, etc. Politics is always state or anti-state. Methods of political regulation of one or other branches of public life, as well as society as a whole, are determined by the fact that the state (even in the presence of opposition) has a monopoly on political power in society.

Politics is a social phenomenon consisting of various (material, social, spiritual) sub-branches of public life. It is believed that this phenomenon covers such elements as political consciousness (mass and individual); political relations, phenomena and processes; political institutions and establishments; political norms. ${ }^{20}$

Therefore, it is possible to make sure that morality, in spite of the widespread interpretation, is not a purely social phenomenon. Proceeding in its implementation far beyond the limits of interpersonal relations, that is, sociality, it can not be reduced to the latter by its very nature, can not be considered only as a derivative from them - just like neither art, nor religion, philosophy, science can be viewed in a similar way. All these forms of spirituality are integral manifestations of a person; however, a

\footnotetext{
${ }^{20}$ урлацкий Ф.М., Галкин А.А. Современный левиафан. - М., 1985. - 382 с. - Ст. 32.
} 
person correlates in their formation and existence with all the surrounding environment, therefore a person can not be reduced to any particular aspect, even to the most obvious to us.

The peculiarity of morality as a means of human activity regulation is in the fact the moral demands and evaluations are directly produced by mass consciousness, approved by society will and claim to be of universal significance, they are perceived and formed in the form of unified behavioral norms as well as principles and ideals having value justification and require understanding of certain individuals in a way of personal conviction and motive for their implementation. And it concerns not only individual acts, behavior of individuals or groups but life order of society as a whole. Having such peculiarities, morality as a means of activity regulation appears as a specific form of consciousness, have moralistic aspects not only of daily individual and group life but the attitude of individuals to the process of historical development as its subject.

Political consciousness is an indirect reflection of the society political life, the essence of which is the problem of power, formation, development and satisfaction of the interests and needs of political subjects. It is clear that some worldview stereotypes (or even archetypes), ideas can be connected with the way how people understand the state and politics only indirectly.

Conscious or unconscious change in the meaning of political ideas can be realized within the time context - from generation to generation, and in case of transferring of one or another idea from one ground to another. Ideas may, depending on a particular situation or one or another social basis, have very unexpected rethinking.

So, the specificity of morality is that it is the most universal form of personal worldview and world perception, active stimulus for social actions, an accumulator of value orientations of an individual, social groups and society as a whole, a regulator of public-political and spiritual processes in society.

\section{REFERENCES}

1. Скрипник А.П. Моральное зло в истории этики и культуры. М.: Политиздат, 1992. - 211 с. 
2. Николаичев Б. Осознаваемое и неосознаваемое в нравственном поведении личности. - М.: Изд.-во МГУ, 1976. - 96 с.

3. Леонтьев А. Деятельность. Сознание. Личность. - М., Наука, 1989. $-566 \mathrm{c}$.

4. Уледов А. Структура общественного сознания. - М.: Мысль, 1988. $-324 \mathrm{c}$.

5. Дробницкий О.Г. Проблемы нравственности. - М.: Наука, 1977. $-333 \mathrm{c}$.

6. Титаренко А.И. Структуры нравственного сознания. - М.: Мысль 1974. - 278 с.

7. Шердаков В. Аксиология и этика. Тбилиси: Изд.-во Тбилиского университета, 1990. - $168 \mathrm{c}$.

8. Гумницкий Г. Основные проблемы теории морали. - Иваново, 1992. $-227 \mathrm{c}$.

9. Ротницкий В.Диалектика форм общественного сознания. Тюмень: Изд.-во Тюменьского университета, 1993. - 356 с.

10. Василенко В. Сознание и бытие в структуре нравственного феномена. - М.: Наука, 1991. - 166 с.

11. 135 Новиков Б.В. Контуры духовности. Новые контексты идентификации // Вопросы философии. -1992. - № 12. - С. 21-41.

12. Монтень М. Опыты в 3-х кн. - М.: Голос, 1992, кн. 1. -383 с.

13. Мур Дж. Принципы этики. - М.: Прогресс, 1984. - 326 с.

14. Кант И. Основы метафики нравственности. - М.: Мысль, 1999. $-528 \mathrm{c}$.

15. Бурлацкий Ф.М., Галкин А.А. Современный левиафан. - М., 1985. $-382 \mathrm{c}$.

\section{Information about the author: Tymoshenko T. S.}

Candidate of Philosophical Sciences, Assistant Professor at the Department of Philosophy and History Educational-Scientific Humanitarian Institute

V. I. Vernadsky Taurida National University, 33, Ivana Kudri str., Kyiv, 01042, Ukraine. 